\title{
The inhibitory effect of anthocyanins on Akt on invasion and epithelial-mesenchymal transition is not associated with the anti-EGFR effect of the anthocyanins
}

\author{
JING NAN LU ${ }^{1,8}$, WON SUP LEE ${ }^{1}$, MIN JEONG KIM ${ }^{1}$, JEONG WON YUN ${ }^{1}$, JI HYUN JUNG $^{1}$, \\ SANG MI YI ${ }^{1}$, JAE-HOON JEONG ${ }^{3}$, HYE JUNG KIM ${ }^{2}$, YUNG HYUN CHOI ${ }^{4}$, \\ GON-SUP KIM ${ }^{5}$, CHUNG HO RYU ${ }^{7}$ and SUNG CHUL SHIN ${ }^{6}$
}

\begin{abstract}
Departments of ${ }^{1}$ Internal Medicine and ${ }^{2}$ Pharmacology, Institute of Health Sciences, Gyeongsang National University School of Medicine, Jinju; ${ }^{3}$ Research Center for Radiotherapy, Korea Institute of Radiological and Medical Sciences, Seoul; ${ }^{4}$ Department of Biochemistry, Dongeui University College of Oriental Medicine and Anti-Aging Research Center and Blue-Bio Industry RIC, Dongeui University, Busan; ${ }^{5}$ School of Veterinary Medicine and ${ }^{6}$ Department of Chemistry and Research Institute of Life Science, ${ }^{7}$ Division of Applied Life Science (BK 21 Program), Institute of Agriculture and Life Science, Gyeongsang National University, Jinju, Republic of Korea
\end{abstract}

Received December 18, 2013; Accepted February 13, 2014

DOI: $10.3892 /$ ijo.2014.2315

\begin{abstract}
Evidence suggests that anthocyanins inhibit EGFR and Akt activity. However, it is still unknown whether the inhibitory effect of anthocyanins on Akt is associated with the anti-EGFR effect. The effect of anthocyanins on epithelialmesenchymal transition (EMT) has not been extensively studied. Therefore, we investigated the effects of anthocyanins from fruits of Vitis coignetiae Pulliat (AIMs) on EGF-induced EMT and the underlying molecular mechanisms. AIMs suppressed the invasion of A549 cells in a dose-dependent manner. AIMs inhibited the phosphorylation of Akt and EGFR, but the inhibitory effect on Akt was not derived from EGFR. EGF re-induced Akt phosphorylation at Thr308 in the AIM-treated cells, but not Akt phosphorylation at Ser473. AIMs also inhibited EMT of cancer cells. AIMs inhibited glycogen synthase kinase- $3 \beta$ phosphorylation and $\beta$-catenin expression that are invovled in EMT. We confirmed these findings with transforming growth factor (TGF)- $\beta$. In conclusion, these data suggest that the inhibitory effect of AIMs on Akt
\end{abstract}

Correspondence to: Professor Won Sup Lee, Department of Internal Medicine, Division of Hematology-Oncology, Gyeongsang National University School of Medicine, 90 Chilam-dong, Jinju 660-702, Republic of Korea

E-mail: lwshmo@hanmail.net; lwshmo@gnu.ac.kr

Present address: ${ }^{8}$ The Fifth Hospital of Shijiazhuang, Shijiazhuang 050021, P.R. China

Key words: anthocyanins, Vitis coignetiae Pulliat, epidermal growth factor receptor, phosphatidylinositol-3 kinase/Akt, epithelialmesenchymal transition activity is independent of EGFR, and that AIMs suppressed invasion and migration at least in part by suppressing EMT by inhibiting Akt activity as well as EGFR. This study provides evidence that AIMs may have anticancer effects on human cancer cells.

\section{Introduction}

Cancer still ranks first as the leading cause of death. After development of cancer, the cancer cells start to invade the vascular and lymphatic channels, and then spread to farther regional nodes and distant organs. Therefore, much attention has been paid to the control of cancer invasion and metastasis. In the progression of cancer invasion and metastasis, growth factors and cytokines play an important role. Especially, epidermal growth factor (EGF) is reported to promote tumor cell motility and invasion and to be implicated in tumor progression (1-3), and the overexpression of EGF receptor (EGFR) has shown the poor clinical outcome $(4,5)$. In the process of invasion, matrix matalloproteinases (MMPs) play a critical role in degradation of extracellular matrix (ECM). In addition to this degradation, epithelial cancer cells need to change to metastasize to other organs. Epithelial-mesenchymal transition (EMT) is one of the hypothetical processes for epithelial cancer cells to metastasize; it causes cancer cells to lose epithelial characteristics and acquire invasive properties and stem cell-like features (6).

Vitis coignetiae Pulliat (Meoru in Korea) has been used as a Korean folk medicine for the treatment of inflammatory disorders and cancer. Its fruit has an intense dark red hue, reflecting an abundance of anthocyanins. The anthocyanins reportedly have inhibitory effect on tyrosine kinase of EGFR (7). We reported that anthocyanins isolated from Meoru (AIMs) have anticancer property by inhibiting Akt activity (8). However, it is still unknown whether the inhibitory effects of AIMs on Akt was derived from the anti-EGFR effects of 
AIMs. Moreover, few studies have been conducted regarding the effects of anthocyanins on EMT. Therefore, we investigated the effects of AIMs on cellular responses and molecular changes in EGF-treated human lung cancer cells in terms of cancer invasion and EMT.

\section{Materials and methods}

Cell culture and chemicals. A549 human lung cancer cells from the American Type Culture collection (Rockville, MD, USA) were cultured in RPMI-1640 medium (Invitrogen, Carlsbad, CA, USA) supplemented with $10 \%$ (v/v) fetal bovine serum (FBS) (Gibco-BRL, Grand Island, NY, USA), $1 \mathrm{mML}$-glutamine, $100 \mathrm{U} / \mathrm{ml}$ penicillin, and $100 \mu \mathrm{g} / \mathrm{ml}$ streptomycin at $37^{\circ} \mathrm{C}$ in a humidified atmosphere of $95 \%$ air and $5 \% \mathrm{CO}_{2}$ incubator. Molecular mass markers for proteins were obtained from Pharmacia Biotech (Saclay, France). Antibodies against phospho-Akt serine (Ser)473, Akt 1/2/3 (H-136), COX-2 (29), cyclin D1 (M-20), c-Myc, extracellular-regulated kinase (ERK), phospho-ERK (E-4), E-cadherin (6F9), MMP-2, MMP-9, phospho-p70S6 kinase $\alpha$ (Thr389), $\beta$-catenin (H-102), XIAP, Bcl-2, were purchased from Santa Cruz Biotechnology (Santa Cruz, CA, USA). Antibodies against phospho -IKB- $\alpha$ (Ser32/36), vimentin (D21H3), Snail (C15D3), N-cadherin, phosphorylated (p)-GSK-3 $\beta$ (Ser9), phospho-Akt (Thr308) were purchased from Cell Signaling Technology (Beverly, MA, USA). Antibodies against EGFR, and phospho-EGFR were purchased from Upstate Biotech (Waltham, MA, USA). Antibody against $\beta$-actin was from Sigma (Beverly, MA, USA). Peroxidase-labeled donkey anti-rabbit and sheep anti-mouse immunoglobulin, and an enhanced chemiluminescence (ECL) kit were purchased from Amersham (Arlington Heights, IL, USA). All other chemicals not specifically cited here were purchased from Sigma Chemical (St. Louis, MO, USA).

Preparation of anthocyanins. Fruits of Meoru were collected in the middle of September 2008 at Jiri Mountain, Korea and freezedried and stored in dark glass containers at $-20^{\circ} \mathrm{C}$ until required for analysis. Anthocyanin pigments were isolated as previously described (9). The composition of anthocyanins isolated from Meoru (AIMs) was as follows: delphinidin-3,5-diglucoside: cyanidin-3,5-diglucoside:petunidin-3,5-diglucoside:delphinidin3-glucoside:malvdin-3,5-diglucoside:peonidin-3,5-diglucoside: cyanidin-3-glucoside:petunidin-3-glucoside:peonidin-3-glucoside: malvidin-3-glucoside $=3.5: 3.4: 7.1: 23.9: 8.0: 9.6: 9.1: 16.1: 5.7: 13.4$.

Cell proliferation assays. For the cell viability assay, A549 cells were seeded onto 24 -well plates at a concentration of $5 \times 10^{4}$ cells $/ \mathrm{ml}$ and treated with AIMs for $24 \mathrm{~h}$ and the number of surviving cells was counted using trypan blue exclusion methods.

Cell invasion assay. For the cell invasion assays, A549 cells were cultured in serum-free media overnight. Cells $\left(5 \times 10^{4}\right)$ were loaded onto pre-coated Matrigel 24-well invasion chambers (BD Biosciences, San Jose, CA, USA) with and without AIMs. Then $0.5 \mathrm{ml}$ of medium containing 20\% FBS was added to the wells of the plate to serve as a chemo-attractant and incubated for $24 \mathrm{~h}$ at $37^{\circ} \mathrm{C}$ in $5 \% \mathrm{CO}_{2}$. After removing non-migrated or non-invaded cells, cells on the bottom filter surface were fixed with $10 \%$ formalin, stained with DAPI and counted.

Gelatin zymography. The gelatinolytic activities for MMP-2 and MMP-9 in the culture medium were assayed by electrophoresis on $10 \%$ polyacrylamide gels containing $1 \mathrm{mg} / \mathrm{ml}$ gelatin at $4^{\circ} \mathrm{C}$. Polyacrylamide gels were run at $120 \mathrm{~V}$, washed in $2.5 \%$ Triton $\mathrm{X}-100$ for $1 \mathrm{~h}$, and then incubated for $16 \mathrm{~h}$ at $37^{\circ} \mathrm{C}$ in activation buffer $(50 \mathrm{mM}$ Tris- $\mathrm{HCl}, \mathrm{pH} 7.5,10 \mathrm{mM}$ $\mathrm{CaCl}_{2}$ ). After staining with Coomassie Blue (10\% glacial acetic acid, $30 \%$ methanol and $1.5 \%$ Coomassie brilliant Blue) for 2-3 h, the gel was washed with a solution of $10 \%$ glacial acetic acid and 30\% methanol without Coomassie Blue for $1 \mathrm{~h}$. White lysis zones indicating gelatin degradation were revealed by staining with Coomassie brilliant Blue.

Wound healing assay. A549 cells were grown on $30 \mathrm{~mm}$ dish plate to $100 \%$ confluent monolayer and then scratched to form a $100-\mu \mathrm{m}$ 'wound' using sterile pipette tips. The cells were then cultured in the presence or absence of AIMs $(400 \mu \mathrm{g} / \mathrm{ml})$ in serum-free media for $24 \mathrm{~h}$. The images were recorded at 12 and $24 \mathrm{~h}$ after scratch using an Olympus photomicroscope.

Western blot analysis. The concentrations of cell lysate proteins were determined by means of the Bradford protein assay (Bio-Rad Laboratories, Richmond, CA, USA) with bovine serum albumin as a standard. For the western blot analysis, $30 \mu \mathrm{g}$ of proteins were resolved by electrophoresis, eletrotransferred to a polyvinylidene difluoride membrane (Millipore, Bedford, MA, USA), and then incubated with primary antibodies followed by secondary antibody conjugated to peroxidase. Blots were developed with an ECL detection system.

Statistical analysis. Each experiment was performed in triplicate. The results were expressed as means \pm SD. Significant differences were determined using the one-way analysis of variance (ANOVA) with Neuman-Keuls post hoc test in the cases at least three treatment groups and Student's t-test for two group comparison. Statistical significance was defined as $\mathrm{P}<0.05$.

\section{Results}

AIMs suppressed the proliferation and invasion of A549 cells in a dose-dependent manner. At first, the growth of A549 cancer cells was assessed by trypan blue exclusion method. It revealed that the growth of A549 cells start to decline at the concentration of $200 \mu \mathrm{g} / \mathrm{ml}$, and the inhibitory effects finally reached a statistical significant level at the concentration of $400 \mu \mathrm{g} / \mathrm{ml}$ (Fig. 1A). Next, we tested the effects of AIMs on cell invasion, because cancer cell invasion is the first step in cancer metastasis. AIMs significantly inhibited A549 cell invasion in a dose-dependent manner as measured by Matrigel invasion assays, compared to the effects of AIMs on cell growth (Fig. 1B). To verify the molecular mechanisms, we measured the secreted MMP-2 and MMP-9 by gelatin zymographic analyses using culture media because secreted MMPs are key molecules in degradation of the extracellular matrix (ECM) $(10,11)$. As indicated in Fig. 1C, AIMs have markedly 
A

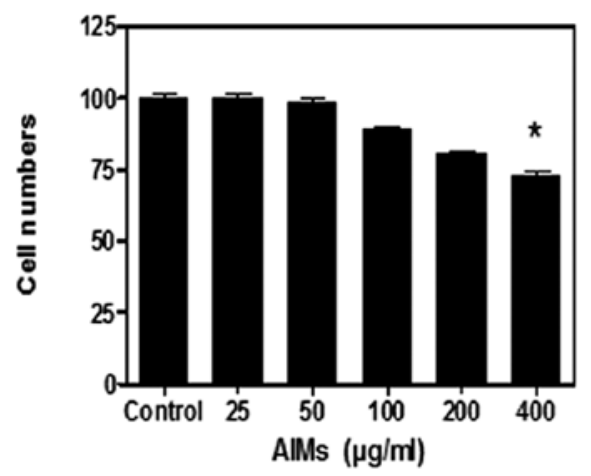

B

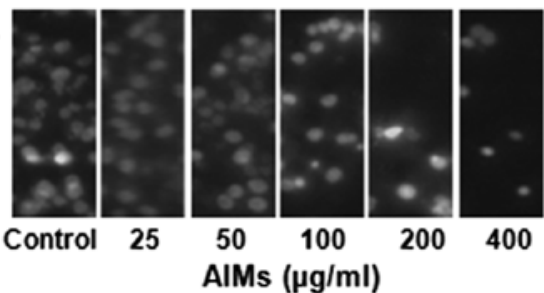

C

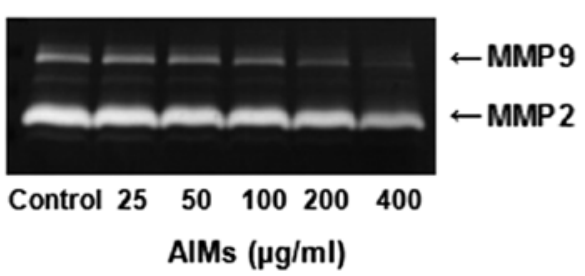

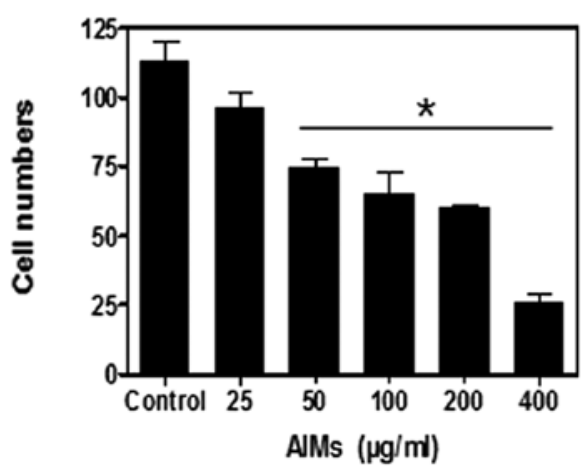

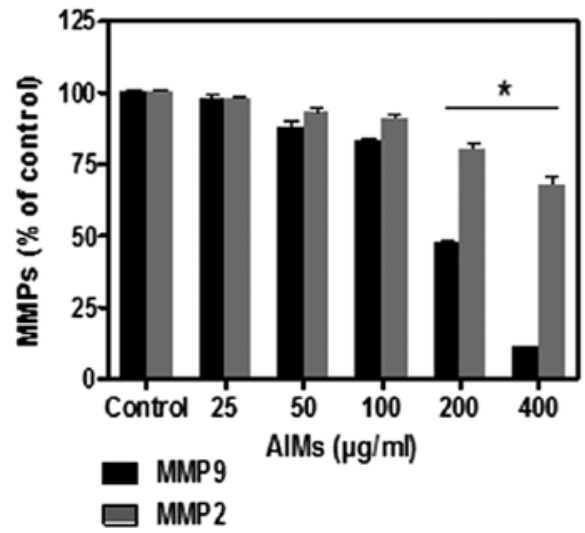

Figure 1. A dose-dependent inhibitory effect of AIMs on invasion of A549 human lung cancer cells. (A) Growth viability assay for AIMs in A549 cells. Cells were seeded at $5 \times 10^{4}$ cells $/ \mathrm{ml}$ and treated with AIMs for $24 \mathrm{~h}$ with the indicated concentrations $(0-400 \mu \mathrm{g} / \mathrm{ml})$. (B) Effects on invasion of A549 cells. A549 cells were treated with AIMs $(0-400 \mu \mathrm{g} / \mathrm{ml})$ for $18 \mathrm{~h}$ in a Matrigel-coated Transwell. (C) Secreted MMP-2 and MMP-9 proteins measured by gelatin zymography. Cells were incubated for $24 \mathrm{~h}$ with AIMs $(0-400 \mu \mathrm{g} / \mathrm{ml})$. Values represent means $\pm \mathrm{SD}$ from four independent experiments. ${ }^{*} \mathrm{P}<0.05 \mathrm{vs}$. control.

suppressed the gelatinolytic activities of secreted MMP-9 in a dose-dependent manner, compared to the effects on MMP-2. These finding suggested that AIMs inhibit invasion predominantly by suppressing MMP-9 secretion.

EGF reduced the inhibitory effects of AIMs on cancer invasion other than an increase in MMP-2 and MMP-9 secretion. The human lung adenocarcinoma cell line A549 was frequently used for EGF effects on cancer cells (12). Since EGF-induced signaling is involved in cancer cell invasion $(13,14)$, we also performed Matrigel invasion test to confirm whether EGF-promoted cell invasion. Matrigel invasion test revealed that EGF promoted cell invasion, and that AIMs inhibited the EGF-induced cell invasion (Fig. 2A). Interestingly, the degree of the anti-invasive effects of AIMs on EGF treated cells was not as strong as those on control cells. To investigate the molecular mechanisms of the augmented effects of EGF on cancer invasion as well as the anti-invasive effects of AIMs, we measured the secreted MMP-2 and MMP-9 by the gelatin zymography. Inconsistent with the results of invasion test of
AIMs, the effects of AIMs on MMP-2 and MMP-9 activities was of no difference between control and EGF treated group (Fig. 2C). This result suggested that EGF-augmented invasion is not caused by the increased secretion of MMP-2 or MMP-9, but by another mechanism.

AIMs inhibited the phosphorylation of Akt and EGFR, and the inhibitory effect of AIMs on Akt was derived from the anti-EGFR activity of AIMs. It has been suggested that anthocyanins inhibit tyrosine kinase activity of EGFR (7), and that AIMs have anticancer effects by inhibiting phosphatidylinositol (PI)-3 kinase (PI3K)/Akt pathway (8). To determine whether the inhibitory effects of AIMs on Akt was derived from the anti-EGFR effects of AIMs as well as to investigate the molecular mechanisms of the anti-invasive effects of AIMs, we assessed the effects of AIMs on phosphorylation of Akt, p70S6K (Thr389), and ERK as well as EGFR in both EGF-treated and EGF-untreated cells. Western blot analysis revealed that AIMs suppressed EGFR phosphorylation and the downstream molecules [Akt, p70S6K (Thr389) and ERK] time-dependently (Fig. 3A). Next, 
A
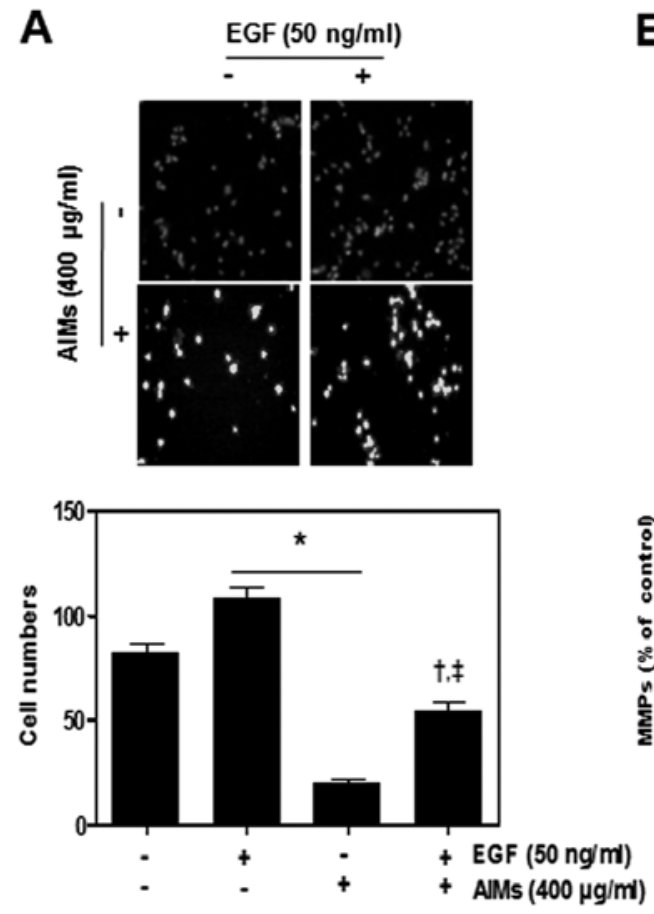

B

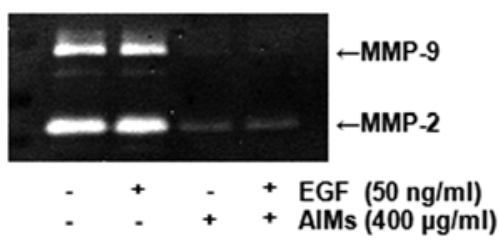

C

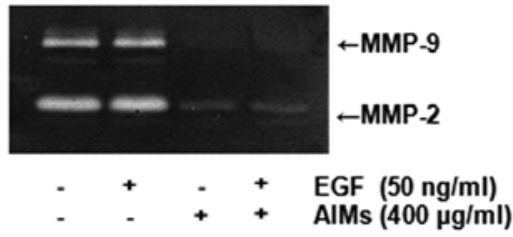

Figure 2. EGF-induced effects on cancer invasion and MMP-2 and MMP-9 secretion in A549 cells treated with or without AIMs. (A) Cells were serum-starved for $24 \mathrm{~h}$ with or without AIMs $(400 \mu \mathrm{g} / \mathrm{ml})$. Cells $\left(5 \times 10^{4}\right.$ cells) were loaded onto pre-coated Matrigel 24-well invasion chambers in the presence or absence of EGF $(50 \mathrm{ng} / \mathrm{ml})$. The Matrigel invasion chambers were incubated for $24 \mathrm{~h}$. ${ }^{\prime} \mathrm{P}<0.05$ vs. control, ${ }^{\dagger} \mathrm{P}<0.05$ vs. AIMs. (B and C) MMP-2 and MMP-9 protein levels were measured by gelatin zymography. Cells were incubated for $24 \mathrm{~h}$ without or with AIMs (1- and 24-h pre-treatment). The gelatinolytic activity was measured by densitometry and represent means $\pm \mathrm{SD}$ from three independent experiments. $* \mathrm{P}<0.05$ vs. control.

A

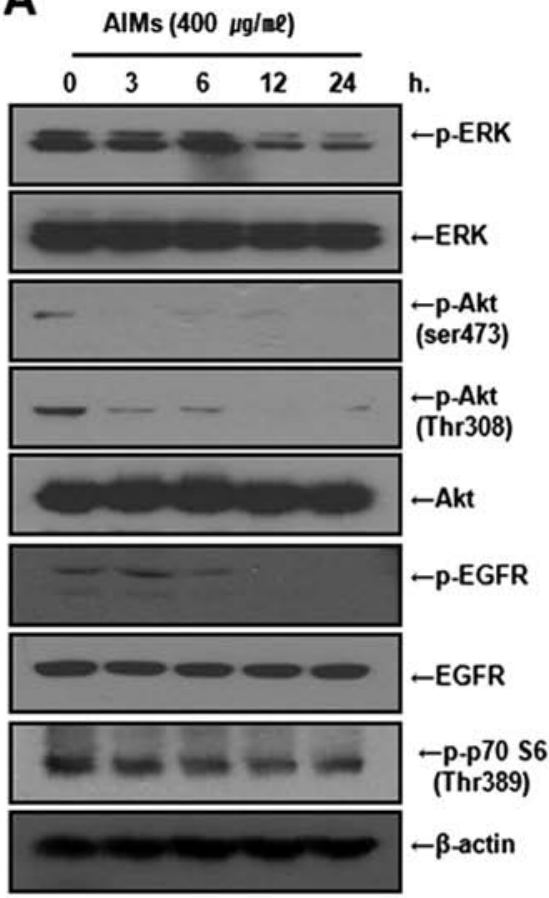

B

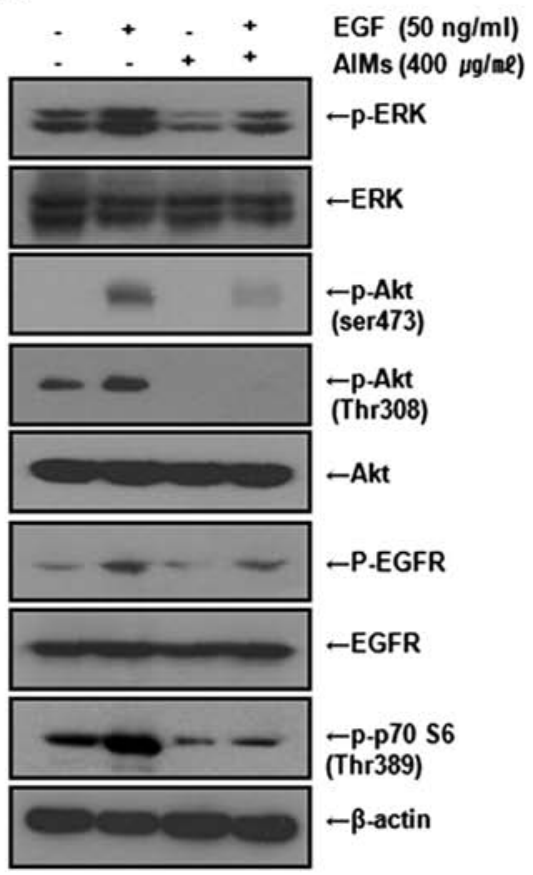

C

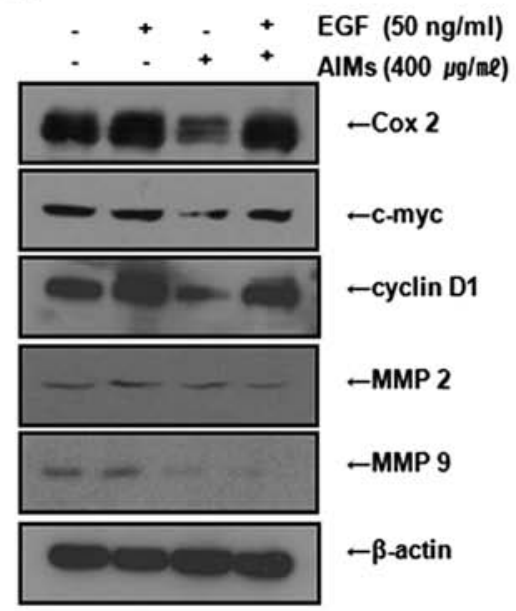

Figure 3. The inhibitory effects of AIMs on the phosphorylation of Akt and ERK as well as EGFR. Western blot analysis for phospho-Akt (Thr308, and Ser473), Akt, phospho-ERK, ERK, phospho-EGFR, and EGFR in A549 cells. (A) Cells $\left(5 \times 10^{4}\right.$ cells) were pretreated with AIMs ( $\left.400 \mu \mathrm{g} / \mathrm{ml}\right)$ for the indicated times and lysed. Equal amounts of the cell lysate were separated by SDS-polyacrylamide gels and then transferred to nitrocellulose membranes. The membranes were probed with the indicated antibodies and detected by an ECL detection system. (B) Cells (5x10 cells) were pretreated with AIMs (400 $\mu \mathrm{g} / \mathrm{ml})$ for $1 \mathrm{~h}$ and then treated with EGF (50 ng/ml) for $24 \mathrm{~h}$. (C) Western blot analysis for COX-2, c-Myc, cyclin D1, MMP-2 and MMP-9 in A549 cells. Cells (5x104 cells), either left untreated or pretreated with AIMs $(400 \mu \mathrm{g} / \mathrm{ml})$ for $1 \mathrm{~h}$ and then were exposed to EGF $(50 \mathrm{ng} / \mathrm{ml})$ for $24 \mathrm{~h}$. Whole-cell extracts were prepared, and $30 \mu \mathrm{g}$ of the whole-cell lysate was analyzed by western blot analysis. The results are representative of two independent experiments. 
A

A549 cells
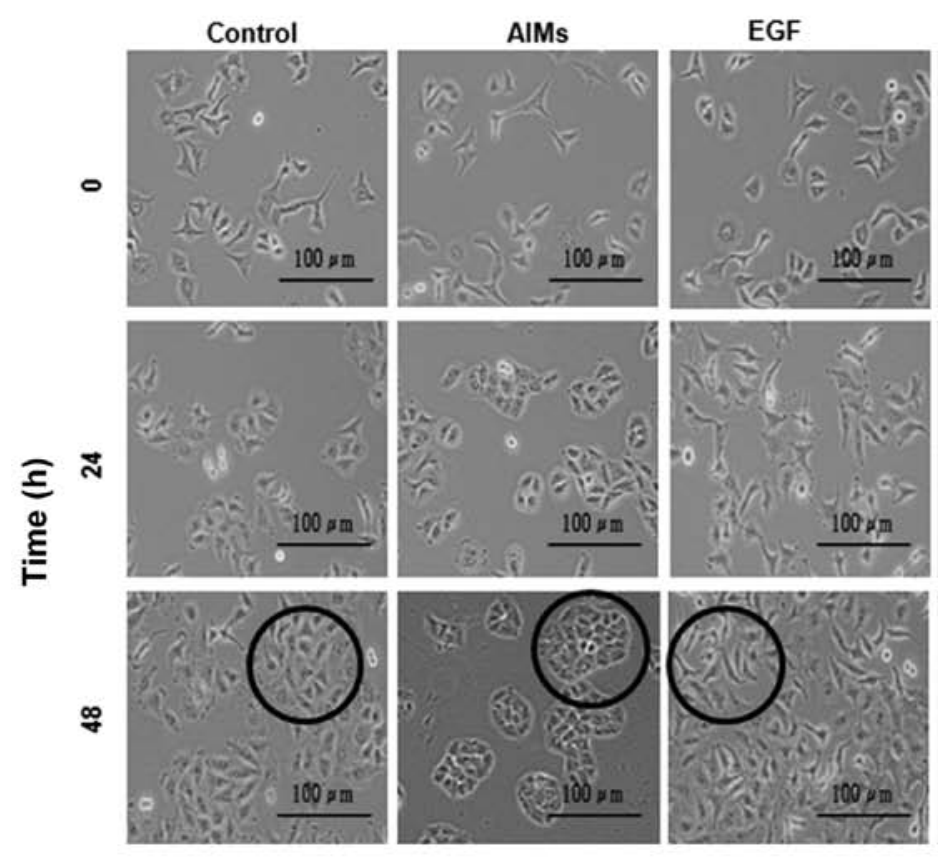

EGF+AIMs

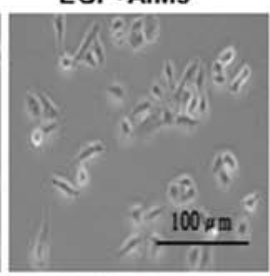

B

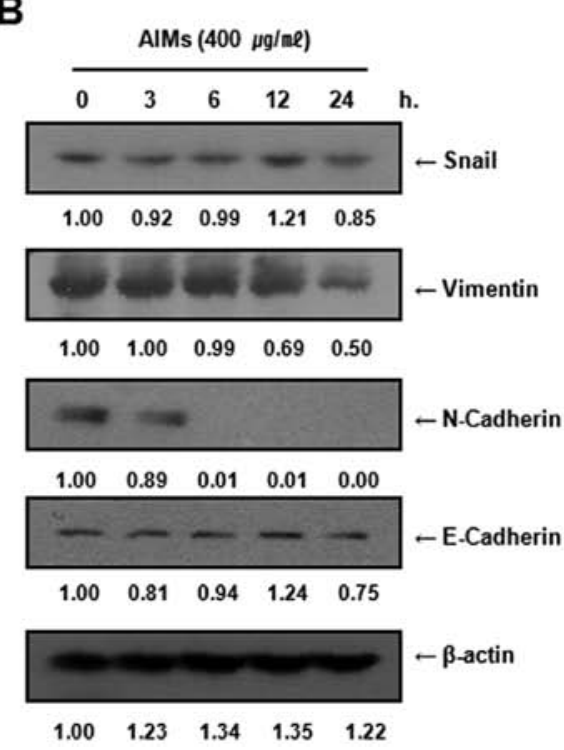

C
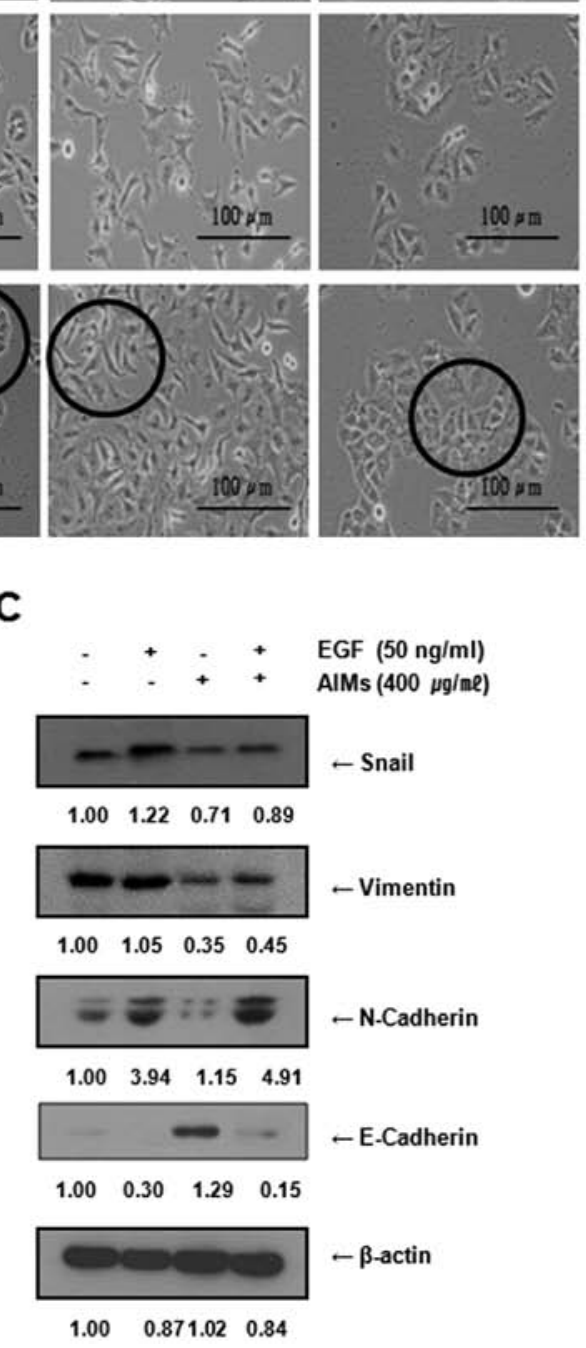

Figure 4. Effects of AIMs on EMT in either EGF-treated or EGF-untreated cells. (A) Cells were pretreated with AIMs (400 $\mu \mathrm{g} / \mathrm{ml})$ for $1 \mathrm{~h}$ and then treated with EGF (50 ng/ml) for $24 \mathrm{~h}$. Data are representative of three independent experiments. (B and C) Western blot analysis for Snail, vimentin, N-cadherin and E-cadherin. Cells $\left(5 \times 10^{4}\right.$ cells) were pretreated with AIMs $(400 \mu \mathrm{g} / \mathrm{ml})$ for the indicated times and lysed. Equal amounts of the cell lysate were separated by SDS-polyacrylamide gels and then transferred to nitrocellulose membranes. The membranes were probed with the indicated antibodies and detected by an ECL detection system. The results are representative of two independent experiments. The expression of the indicated proteins were measured by densitometry and expressed as relative ratio.

we assessed the effects of EGF on these molecules. Western blot analysis revealed that EGF induced phosphorylation of EGFR and the downstream molecules in control cells, and also augmented EGFR and ERK phosphorylation in AIM-treated cells (Fig. 3B). However, EGF did not augment Akt phosphorylation (Thr308) in AIM-treated cells even though it slightly reduced the inhibitory effects of AIMs on Akt (Ser473) and p70S6K which is linked to mTORC1 activation in AIM-treated cells. These findings raised the possibility that the inhibitory effect of AIMs on Akt phosphorylation on Thr308 is not derived from anti-EGFR effect of AIMs. Next, we tested the effects on downstream effector molecules of EGFR involved in cell proliferation and invasion. EGF moderately increased the gene expressions involved in cell proliferation (COX-2, c-Myc and cyclin D1) with an increase in EGFR activity (phosphorylation of EGFR) in either AIM-treated cells or AIM-untreated cells (Fig. 3B and C), but it did not significantly increase the expression of MMP-2 and MMP-9 in AIM-treated cells (Fig. 3C). These finding suggested that AIMs might suppress MMP-2 and MMP-9 expression by inhibiting Akt rather than by inhibiting 
A

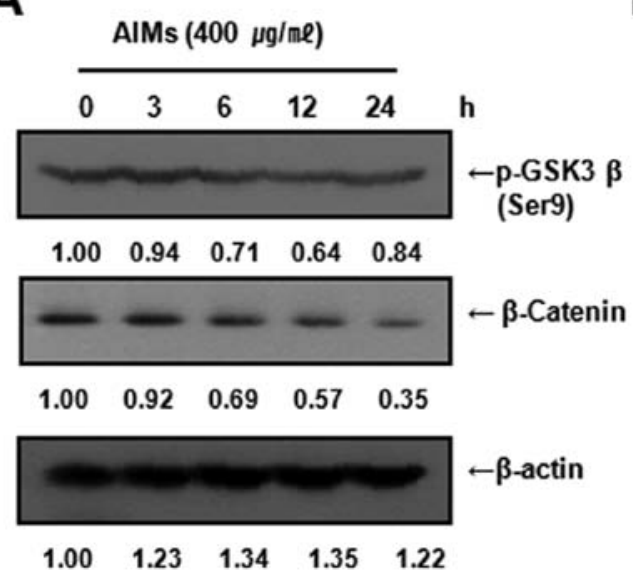

B

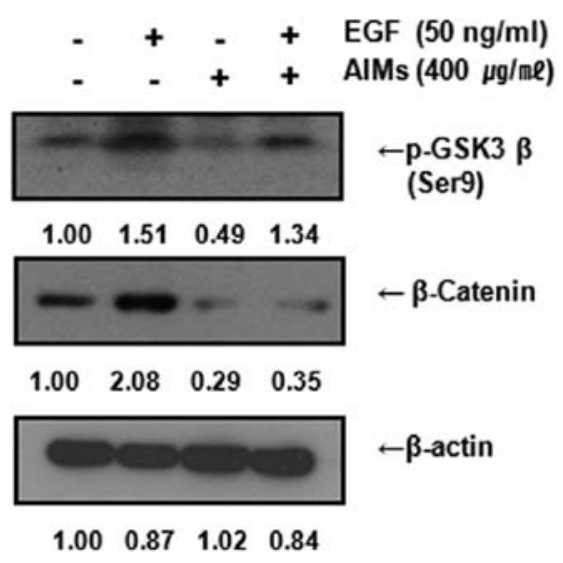

Figure 5. Effects of AIMs on $\beta$-catenin and phosphorylation of Ser9 in glycogen synthase kinase-3 $\beta$ (GSK-3 $\beta$ ). Western blot analysis for $\beta$-catenin and phosphoGSK-3 $\beta$ (Ser9). (A) Cells ( $5 \times 10^{4}$ cells) were pretreated with AIMs $(400 \mu \mathrm{g} / \mathrm{ml})$ for the indicated times and lysed. Equal amounts of the cell lysate were separated by SDS-polyacrylamide gels and then transferred to nitrocellulose membranes. The membranes were probed with the indicated antibodies and detected by an ECL detection system. (B) Cells ( $5 \times 10^{4}$ cells) were pretreated with AIMs ( $\left.400 \mu \mathrm{g} / \mathrm{ml}\right)$ for $1 \mathrm{~h}$ and then treated with EGF $(5 \mathrm{ng} / \mathrm{ml})$ for $24 \mathrm{~h}$. The results are representative of two independent experiments. The expression of the indicated proteins were measured by densitometry and expressed as relative ratio.

EGFR even though EGF-augmented invasion may abide by EGFR activity through activation of Akt signaling as well as ERK signaling.

AIMs inhibited epithelial-mesenchymal transition (EMT) of A549 cells, but not completely in EGF-treated cells. To determine whether EGF induced EMT of A549 cells, and whether AIMs inhibit EGF-induced EMT, we observed the cell morphology of A549 cells for 24 and $48 \mathrm{~h}$ after the treatment of EGF alone or in combination with AIMs. The cell morphology revealed that EGF induced morphological changes of elongation of A549 cells, and that AIMs could not completely prevent the morphological changes (Fig. 4A). To confirm this finding in the molecular level, we next assessed changes in EMT biomarkers after the treatment. Western blot analysis revealed that AIMs suppressed mesenchymal markers such as Snail, vimentin, N-cadherin and induced E-cadherin, an epithelial marker in either EGF-treated or untreated cells (Fig. 4B and C). Consistent with the morphology results, AIMs could not completely suppress the EGF effects on the expression of EMT markers (Fig. 4C) while EGF increased EGFR activity in A549 cells (Fig. 3B). These results indicated that EGF reduced the inhibitory effect of AIMs on EMT with an increase in EGFR activity although AIMs inhibited EMT in either EGF-treated or untreated cells. These findings suggest that EGF-induced EMT may also abide by EGFR activity.

AIMs inhibited EMT at least in part by inhibiting the expression of GSK-3 $\beta$ phosphorylation (Ser9) and $\beta$-catenin. $\beta$-catenin also plays an important role in EMT in cancer $(15,16)$. In the degradation of $\beta$-catenin, when Wnt signaling is not activated, it is degraded by GSK-3-induced phosphorylation, and the enzymatic activity of GSK-3 is regulated by phosphorylation of certain GSK-3 residues. Phosphorylation of GSK-3 $\beta$ on Ser9 is induced by Akt activation, and results in inhibition of GSK-3 (17). Therefore, we assessed the changes in the expression of $\beta$-catenin, and p-GSK-3 $\beta$ (Ser9) after
AIM treatment. Western blot analysis revealed that AIMs suppressed $\beta$-catenin and Ser9 time-dependently (Fig. 5A). Next to determine whether the inhibitory effect of AIMs on $\beta$-catenin and GSK-3 $\beta$ are influenced by EGF, we assessed the expression of $\beta$-catenin and Ser9 after EGF treatment in either AIM-treated or untreated cells. Western blot analysis revealed that the inhibitory effects of AIMs on Ser9 and $\beta$-catenin attenuated by EGF while AIMs clearly inhibited the expression of $\beta$-catenin and Ser9 (Fig. 5B). These results suggest that AIMs inhibited EMT, at least in part, by inhibiting the expression of GSK-3 $\beta$ phosphorylation (Ser9) and $\beta$-catenin.

AIMs suppress EMT and invasion by suppressing Akt activity as well as EGFR activity, but the inhibitory effects of AIMs on Akt are not derived from EGFR. To give more convincing evidence that AIMs inhibit EMT by inhibiting Akt activity as well as EGFR activity, we assessed the effects of inhibition of EGFR downstream pathways (ERK pathway and PI3K/ Akt pathway) on cell migration with the EGF-stimulated cells. Wound healing tests reveled that AIMs partially inhibited the EGF-augmented cell migration just as AIMs inhibited EGF-augmented EMT. The PI3K inhibitor Ly 294002 and the ERK inhibitor PD 98059 both augmented the inhibitory effects of AIMs on migration of A549 cells treated with EGF (Fig. 6A and B), suggesting each of the two downstream pathways of EGFR (ERK pathway and PI3K/Akt pathway) are contributing to EGF-augmented cancer cell migration. Next, using the PI3K inhibitor and the ERK inhibitor, we also assessed the effects of AIMs and/or EGFR on EMT by western blot analysis. It revealed that EGF activated the two downstream pathways in both AIM-treated and AIM-untreated cells, and that the ERK inhibitor PD 98059 or the PI3K/Akt inhibitor LY 294002 inhibited EMT in EGF-treated cells in both AIM-treated and AIM-untreated cells (Fig. 6C). These finding indicated that EGF cannot induce the Akt phosphorylation (Ser473), even though EGF treatment can partially reverse the inhibitory effect of AIMs on EGFR and re-induce Akt phosphorylation 

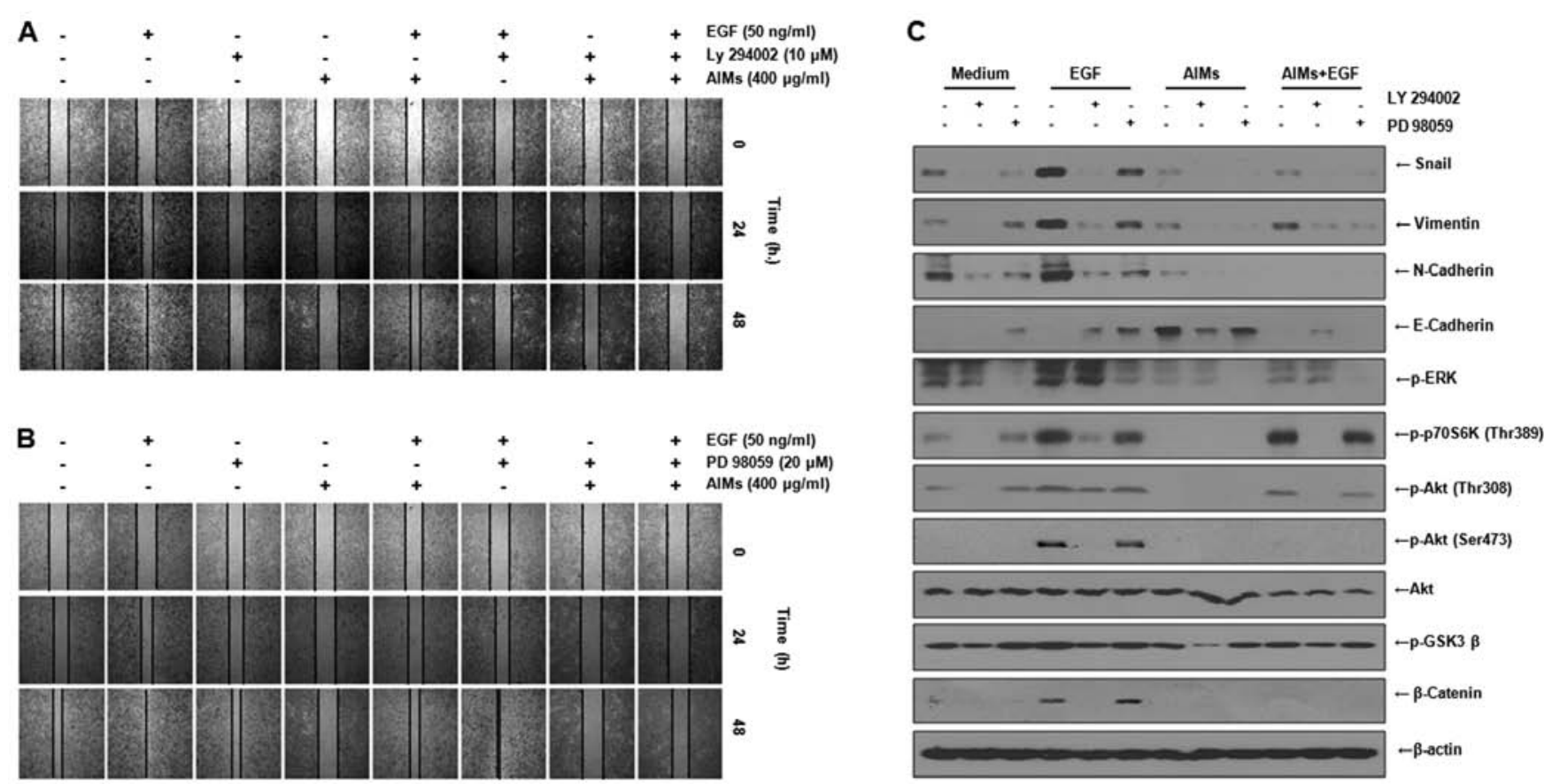

Figure 6. The effects of AIMs on EGFR downstream pathways (ERK pathway and PI3K/Akt pathway) as well as cancer migration and EMT. (A and B) Cells were grown to $100 \%$ confluent monolayer on $30-\mathrm{mm}$ cell culture dishes coated with collagen and then serum-starved for $24 \mathrm{~h}$ with or without EGF (50 ng/ml) and/or indicated agents for $48 \mathrm{~h}$. A linear scratch was made on the culture dish through the cell layer using a pipette tip. (A) Cells were pretreated with AIMs (400 $\mu \mathrm{g} / \mathrm{ml}$ ) and/or Ly $294002(10 \mu \mathrm{M})$ for $1 \mathrm{~h}$ and then treated with EGF (50 ng/ml) for $48 \mathrm{~h}$. (B) Cells were pretreated with AIMs (400 $\mu \mathrm{g} / \mathrm{ml})$ and/or PD 98059 (20 $\mu \mathrm{M})$ for $1 \mathrm{~h}$ and then treated with EGF (50 ng/ml) for $48 \mathrm{~h}$. (C) Cells were pretreated with AIMs (400 $\mu \mathrm{g} / \mathrm{ml})$ and/or indicated agents for $1 \mathrm{~h}$ and then treated with EGF $(50 \mathrm{ng} / \mathrm{ml})$ for $24 \mathrm{~h}$. Whole-cell extracts were prepared and $30 \mu \mathrm{g}$ of the whole-cell lysate was analyzed by western blot analysis with the indicated antibodies. The results are representatives from two independent experiments.

(Thr308) and p-p70S6K (Thr389) in AIM-treated cells. These findings suggested that and AIMs might suppress Akt activity by inhibiting Akt phosphorylation on Ser473 apart from inhibiting EGFR activity.

Taken together, these data also support the finding that cancer migration and EMT in EGF-treated cells abide by EGFR activity through the two EGFR downstream pathways (ERK pathway and PI3K/Akt pathway), and that the inhibitory effect of AIMs on Akt activity may be independent of anti-EGFR activity.

AIMs inhibit transforming growth factor (TGF- $\beta$ )-induced EMT in A549 cells, indicating the inhibitory effect of AIMs on Akt activity is independent of EGFR activity. To confirm that the inhibitory effects of AIMs on Akt pathway is independent of EGFR, we investigated the effects of AIMs on TGF- $\beta$ induced invasion and EMT along with assessing the changes of EMT biomarkers, because TGF- $\beta$ is a well known cytokine involved in invasion and EMT, as well as in augmenting Akt activity independent of EGFR activity. Firstly, to confirm whether TGF- $\beta$ also induces EMT of A549 cells and augments cancer cell invasion, we observed morphological changes and assessed the invasive activity of A549 cells after TGF- $\beta$ treament; TGF- $\beta$ induced elongation of A549 cells (Fig. 7A) and augemented invasion of the cancer cells (Fig. 7B). AIMs inhibited the morphological changes to EMT and the invasive activity even in TGF- $\beta$-treated or TGF- $\beta$-untreated cells, but TGF- $\beta$ also reduced the effects of AIMs on EMT and invasive activity similarly to EGF (Fig. 7A and B). We also measured the expression of the MMPs in AIMs-treated A549 cells by the gelatin zymography analysis. TGF- $\beta$ augmented the expression of MMP-2 and MMP-9 in both AIM-treated and untreated cells, and the pattern of the inhibition of MMP-2 and MMP-9 by AIMs was similar to those shown by EGF; the inhibitory effect of AIMs on MMP-2 and MMP-9 was not influenced by TGF- $\beta$ treatment (Fig. 7C). The protein expression of MMP-2 and MMP-9 revealed by western blot analysis showed similar pattern as the gelatinolytic activity (Fig. 7D). Additionally, to confirm TGF- $\beta$-driven EMT was not associated with EGFR activity, but rather with Akt activity, we assessed the effects of AIMs on phosphorylation of Akt and ERK as well as EGFR. It revealed that TGF- $\beta$ induced Akt phosphorylation, but not EGFR phosphorylation, and that AIMs suppressed the Akt phosphorylation (Ser473) even in TGF- $\beta$-treated cells (Fig. 7E). TGF- $\beta$ re-induced Akt phosphorylation (Thr308) and the downstream molecule p70S6K, which is linked to mTORC1 activation in AIM-treated cells. These findings indicated that AIMs have an inhibitory effect on Akt, independent of antiEGFR effects of AIMs. We also assessed the changes in the molecules involved in EMT. Western blot analysis revealed that AIMs suppressed mesenchymal markers such as Snail, vimentin, $\mathrm{N}$-cadherin and induced $\mathrm{E}$-cadherin, which is an epithelial marker in control cells (Fig. 7F). However, TGF- $\beta$ increased mesenchymal biomarkers as well as GSK-3 $\beta$ phosphorylation and $\beta$-catenin expression in both AIM-treated and AIM-untreated cells. These results confirmed that the inhibitory effect of AIMs on Akt activity is independent of EGFR activity, and AIMs still suppressed Akt phosphorylation on 

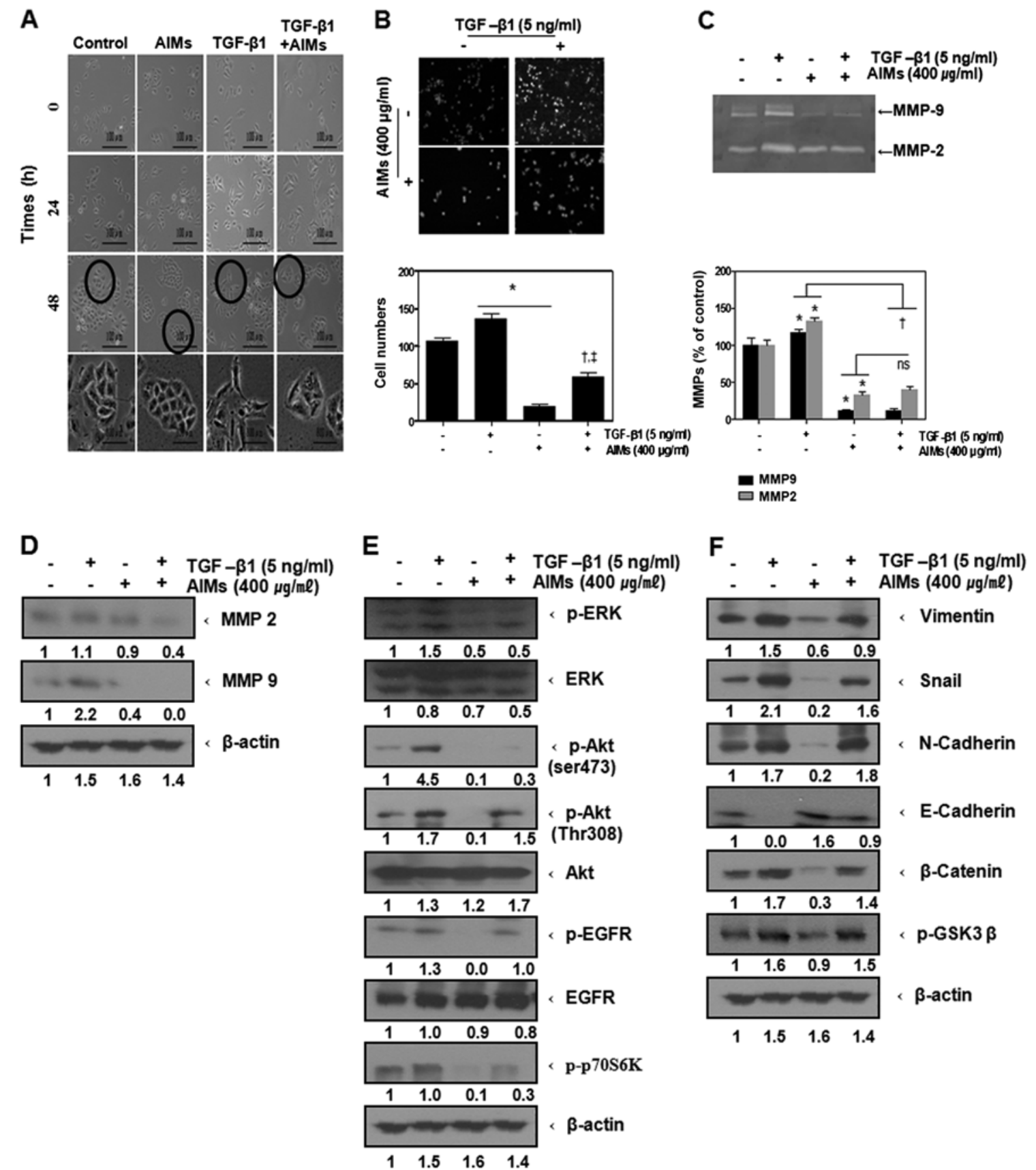

Figure 7. Inhibitory effects of AIMs on TGF- $\beta$-induced invasion and EMT in A549 cells. (A) Cells were pretreated with AIMs (400 $\mu \mathrm{g} / \mathrm{ml})$ for $1 \mathrm{~h}$ and then treated with TGF- $\beta(5 \mathrm{ng} / \mathrm{ml})$ for $24 \mathrm{~h}$. Data are representative of three independent experiments. (B) Cells were serum-starved for $24 \mathrm{~h}$ with or without AIMs $(400 \mu \mathrm{g} / \mathrm{ml})$. Cells $\left(5 \times 10^{4}\right.$ cells) were loaded onto pre-coated Matrigel 24 -well invasion chambers in the presence or absence of TGF- $\beta$ (5 ng/ml). The Matrigel invasion chambers were incubated for $24 \mathrm{~h}$. ${ }^{*} \mathrm{P}<0.05$ vs. control, ${ }^{\dagger} \mathrm{P}<0.05$ vs. AIMs. (C) MMP-2 and MMP-9 protein levels were measured by gelatin zymography. Cells were incubated for $48 \mathrm{~h}$ without or with AIMs. Values represent means \pm SD from three independent experiments. " $\mathrm{P}<0.05$ vs. control. (D-F) Cells (5x10 ${ }^{4}$ cells), either left untreated or pretreated with AIMs $(400 \mu \mathrm{g} / \mathrm{ml})$ for $24 \mathrm{~h}$ and then were exposed to TGF- $\beta$ ( $5 \mathrm{ng} / \mathrm{ml})$ for indicated times. Whole-cell extracts were prepared, and $30 \mu \mathrm{g}$ of the whole-cell lysate was analyzed by western blot analysis for (D) MMP-2 and MMP-9, (E) phospho-Akt (Thr308 and Ser473), Akt, phospho-ERK, ERK, phospho-EGFR and EGFR, and (F) Snail, vimentin, N-cadherin and E-cadherin in A549 cells. The results are representative of two independent experiments. The expression of the indicated proteins were measured by densitometry and expressed as relative ratio.

Ser473 even in TGF- $\beta$-treated cells whereas the inhibitory effects of AIMs on TGF- $\beta$-induced EMT was limited.

\section{Discussion}

This study was designed to answer the question whether the inhibitory effects of AIMs on Akt activity were associated with anti-EGFR effects on cancer invasion, and whether AIMs have anti-EMT effects. Here, we investigated the effects of AIMs on cellular responses and molecular changes involved in cancer invasion and EMT in human lung cancer cells treated with EGF or TGF- $\beta$. We demonstrated that AIMs suppressed PI3k/Akt and EGFR pathway independently in a dual suppression mode, and that AIMs suppressed invasion 


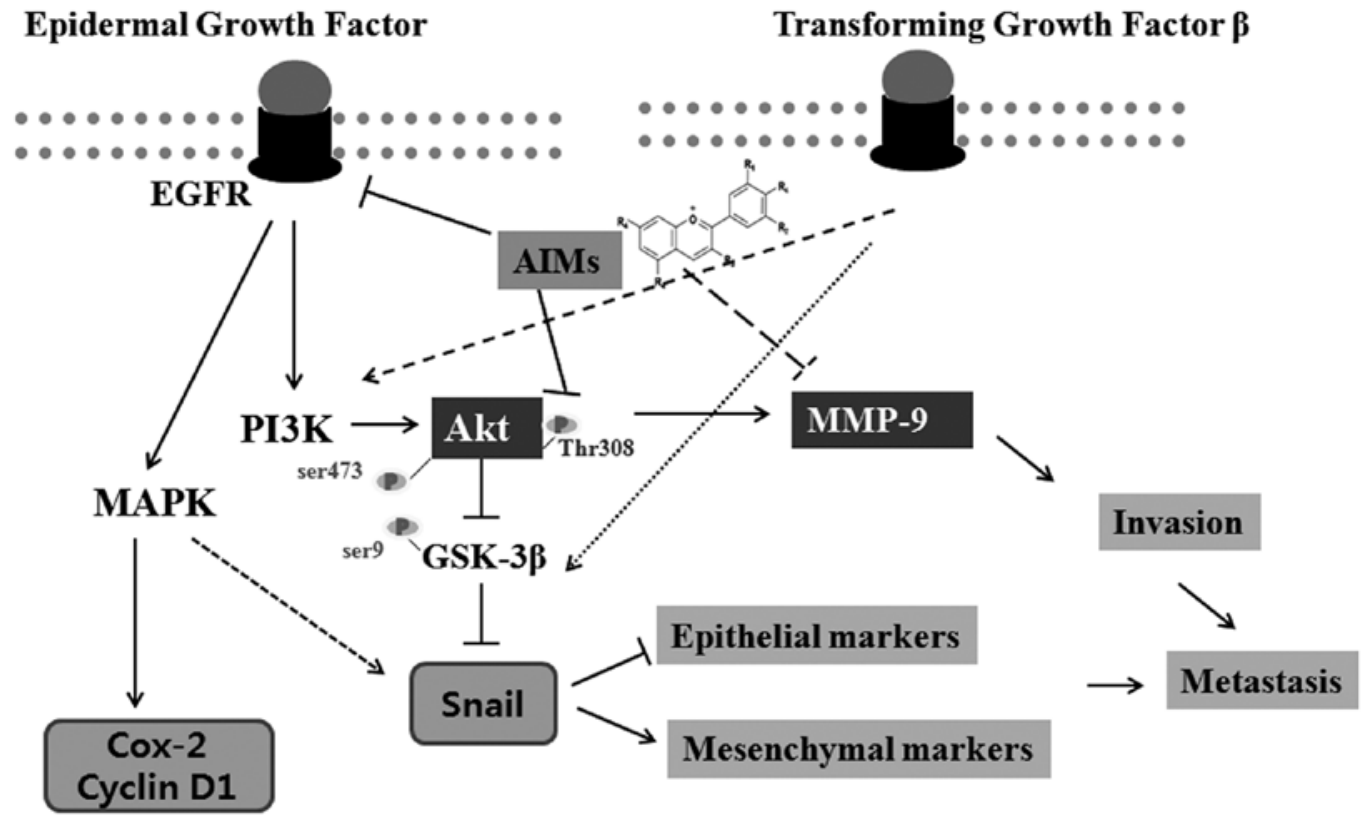

Figure 8. Schematic representation of the inhibitory effects of AIMs on invasion and EMT in A549 human lung cancer cells. EGF activates PI3K/Akt and MAPK pathways. AIMs inhibited invasion and EMT by suppressing the activation EGFR and the downstream pathways (ERK and Akt), but the inhibitory effect of AIMs on Akt was not dependent on the inhibition of EGFR, and is possibly derived from the inhibition of Akt phosphorylation (Thr308). AIMs also inhibit phosphorylation of GSK-3 $\beta$ (Ser9) that is regulated by Akt activity. By inhibiting EGFR and Akt activity in a dual mode, AIMs inhibit invasion and EMT either induced by EGF or TGF- $\beta$, which are well-known factors involved in invasion and EMT. AIMs also inhibited the effector downstream molecules (COX-2 and cyclin D1) that are involved in cell proliferation. This study suggests that AIMs inhibit the invasion and EMT of A549 human lung cancer cells by dual inhibition of Akt and EGFR activity.

and migration at least in part by suppressing EMT. A previous report showed that anthocyanins have anti-EGFR $(7,18)$ and anti-Akt activities (19). Here, we firstly demonstrated that the anti-Akt activity was independent of anti-EGFR activity of anthocyanins in cancer invasion and EMT by using inhibitors for each EGFR downstream pathway (ERK pathway and $\mathrm{PI} 3 \mathrm{~K} / \mathrm{Akt}$ pathway), EGF or TGF- $\beta$ stimulation.

In this study, AIMs predominantly suppressed MMP-9 rather than MMP-2, which was consistent the previous findings which our colleagues demonstrated in HT-29 human colon cancer cells (9). EMT has attracted a great deal of attention as a potential mechanism for tumor cell metastasis (20). Snail is a well-known transcription factor that promotes EMT by repressing the expression of E-cadherin which is important in cell adhesion. With E-cadherin, cancer cells are tightly bound to each other and to stromal cells. To metastasize, cancer cells need to change in order to gain mesenchymal phenotype. Snail is degraded and exported from the nucleus by GSK-3 $\beta$ (21). Here, we demonstrated that EGF induced Snail expression and suppressed E-cadherin expression, and that AIMs inhibited the EGF effects on Snail and E-cadherin. These effects of AIMs on EGF- and TGF- $\beta$ induced EMT were also confirmed in HeLa human uterine cancer cells treated by TNF (data not shown).

However, there are still several findings that are not clearly demonstrated. Both EGF and TGF- $\beta$ enhanced cancer invasion without any further induction of MMP-2 and MMP-9 in the AIM-treated cells (Figs. 2A and B, 7B and $C$ ). This finding indicated that there are other mechanisms for EGF- and TGF- $\beta$-augmented cancer cell invasion rather than the secretion of MMPs. Here, we demonstrated that one of the mechanisms of EGF- and TGF- $\beta$-augmented cancer cell invasion was EMT with assessing the changes in cell morphology and EMT biomarkers. We suggested that AIMs might suppress the secretion of MMP- 2 and MMP- 9 by inhibition of Akt signaling which is well known to regulate MMP-9 expression (22) because of the reports demonstrating that anthocyanins inhibit MMP-2 and MMP-9 by suppression of PI3K/Akt (19). However, this study also suggests that there is a possibility that AIMs inhibit MMP-9 by another mechanism that is not influenced by either EGFR or Akt activity because EGF and TGF- $\beta$ activated Akt activity and EGFR activity in AIM-treated cells.

The effect of AIMs on EMT were different between EGF-treated cells and TGF- $\beta$-treated cells; AIMs partially inhibited EGF-induced EMT, but not TGF- $\beta$-induced EMT although AIMs inhibited Akt phosphorylation on Ser473 in both EGF- and TGF- $\beta$-treated cells. The difference can be explained by the way TGF- $\beta$ induces EMT because TGF- $\beta$ also induces EMT by SMAD-dependent signaling which does not involve Akt activation (23-25).

EGF stimulated the MMPs only slightly compared to those derived from TGF- $\beta$. There are some reports that EGF can induce MMP-9 (26), but in others show that the extent of EGF-induced MMP-9 secretion is far less than that induced by TGF- $\beta$ or tumor necrosis factor (TNF), and that EGF can even inhibit MMP-9 expression in some cancer cells $(27,28)$. The latter finding is consistent with our findings. Another merit of the finding that EGF did not increase MMP-2 and MMP-9 expression give us more valid evidence that EGF did augmented invasion by induction of EMT but not by induction of MMPs. 
We determined whether the inhibitory effect of AIMs on GSK-3 $\beta$ was derived from that on Akt. Previous studies demonstrated that Akt and GSK-3 $\beta$ signaling pathway are involved in EMT (29), and that GSK-3 $\beta$ signaling pathway is dependent on Akt pathway and other signaling such as WNT signaling $(29,30)$. In addition, EGFR signaling pathway is also involved in GSK-3 pathway (31). GSK-3 is encoded by two known genes, GSK- $3 \alpha$ and GSK-3 $\beta$. The site of serine or threonine phosphorylation determines the activity of GSK-3; phosphorylation of Ser9 in GSK-3 $\beta$ significantly decreases the activity of GSK-3. The phosphorylation of Ser9 in GSK-3 $\beta$ is regulated by Akt (17). Therefore, we assessed phosphorylation of Ser9 in GSK-3 $\beta$ to look at GSK-3 activity regulated by Akt. GSK-3 activty is closely linked to $\beta$-catenin activation which is important in EMT. In this study, we found that AIMs suppressed p-GSK-3 $\beta$ (Ser9) and $\beta$-catenin, and that EGF and TGF- $\beta$ enhanced GSK- $3 \beta$ activity by suppressing phosphorylation of Ser9 in GSK-3 $\beta$. These results support that the inhibitory effects of AIMs on GSK-3 $\beta$ activity is derived from the anti-Akt effects. Up to now, few studies has been performed regarding the effects of anthocyanins on GSK-3. There is a report that cyanidin-3-glucoside upregulated p-GSK-3 $\beta$ (Ser9) in a neuroblastoma cell line (32). The result was opposite to ours. However, there is another study supporting our results, which showed that the extract of skin of Muscadine grape containing abundant anthocyanins suppressed p-GSK-3 $\beta$ (Ser9) (33). In that our anthocyanins were isolated from fruit, it is likely that the latter study would be more similar to ours.

Although we demonstrated that EGF and TGF- $\beta$ re-induced into AIM-treated cells the p70S6K linked to mTORC-1 signaling activation with Akt phosphorylation on Ser473, but not on Thr308, this finding is different from the rescent finding that EGFR-mediated activation of mTORC-1 signaling is by Akt phosphorylation on Ser473, not Akt phosphorylation on Thr308. However, this study demonstrated that the inhibition of both mTORC1 and mTORC2 activity lead to activation of EGFR followed by mTORC-1 signaling activation through Akt phosphorylation on Thr308. However, it does not indicate that EGF induced Akt activation should follow the same pathway. There is one report showing exactly the same pattern of Akt activation by EGF stimulation with or without sirolimus (rapamycin) treatment (34).

In conclusion, this study suggests that the inhibitory effect of AIMs on Akt activity is independent of that on EGFR, and that AIMs suppressed invasion and migration, at least in part, by suppressing EMT by inhibiting Akt activity as well as EGFR (Fig. 8). This study provides evidence that AIMs have anti-metastatic effects on human lung cancer by inhibition of both PI3k/Akt and EGFR pathways involved in invasion and EMT.

\section{Acknowledgements}

This study was supported by a grant of the National R\&D Program for Cancer Control, Ministry for Health, Welfare and Family Affairs, Republic of Korea (0820050).

\section{References}

1. Wells A: Tumor invasion: role of growth factor-induced cell motility. Adv Cancer Res 78: 31-101, 2000.

2. Price JT, Wilson HM and Haites NE: Epidermal growth factor (EGF) increases the in vitro invasion, motility and adhesion interactions of the primary renal carcinoma cell line, A704. Eur J Cancer 32A: 1977-1982, 1996.

3. Sieg DJ, Hauck CR, Ilic D, Klingbeil CK, Schaefer E, Damsky $\mathrm{CH}$, et al: FAK integrates growth-factor and integrin signals to promote cell migration. Nat Cell Biol 2: 249-256, 2000.

4. Gullick WJ: Prevalence of aberrant expression of the epidermal growth factor receptor in human cancers. Br Med Bull 47: 87-98, 1991.

5. Salomon DS, Brandt R, Ciardiello F and Normanno N: Epidermal growth factor-related peptides and their receptors in human malignancies. Crit Rev Oncol Hematol 19: 183-232, 1995.

6. Rhim AD, Mirek ET, Aiello NM, Maitra A, Bailey JM, McAllister F, et al: EMT and dissemination precede pancreatic tumor formation. Cell 148: 349-361, 2012.

7. Meiers S, Kemeny M, Weyand U, Gastpar R, von Angerer E and Marko D: The anthocyanidins cyanidin and delphinidin are potent inhibitors of the epidermal growth-factor receptor. J Agric Food Chem 49: 958-962, 2001.

8. Shin DY, Lee WS, Lu JN, Kang MH, Ryu CH, Kim GY, et al: Induction of apoptosis in human colon cancer HCT-116 cells by anthocyanins through suppression of Akt and activation of p38-MAPK. Int J Oncol 35: 1499-1504, 2009.

9. Yun JW, Lee WS, Kim MJ, Lu JN, Kang MH, Kim HG, et al: Characterization of a profile of the anthocyanins isolated from Vitis coignetiae Pulliat and their anti-invasive activity on HT-29 human colon cancer cells. Food Chem Toxicol 48: 903-909, 2010.

10. Vihinen P and Kahari VM: Matrix metalloproteinases in cancer: prognostic markers and therapeutic targets. Int J Cancer 99: 157-166, 2002.

11. Deryugina EI and Quigley JP: Matrix metalloproteinases and tumor metastasis. Cancer Metastasis Rev 25: 9-34, 2006.

12. Goldkorn T, Balaban N, Matsukuma K, Chea V, Gould R, Last J, et al: EGF-receptor phosphorylation and signaling are targeted by $\mathrm{H}_{2} \mathrm{O}_{2}$ redox stress. Am J Respir Cell Mol Biol 19: 786-798, 1998.

13. Carpenter $\mathrm{G}$ and Cohen S: Epidermal growth factor. J Biol Chem 265: 7709-7712, 1990.

14. Margolis B, Bellot F, Honegger AM, Ullrich A, Schlessinger J and Zilberstein A: Tyrosine kinase activity is essential for the association of phospholipase C-gamma with the epidermal growth factor receptor. Mol Cell Biol 10: 435-441, 1990.

15. Li Y, Welm B, Podsypanina K, Huang S, Chamorro M, Zhang $\mathrm{X}$, et al: Evidence that transgenes encoding components of the Wnt signaling pathway preferentially induce mammary cancers from progenitor cells. Proc Natl Acad Sci USA 100: 15853-15858, 2003.

16. Chu EY, Hens J, Andl T, Kairo A, Yamaguchi TP, Brisken C, et al: Canonical WNT signaling promotes mammary placode development and is essential for initiation of mammary gland morphogenesis. Development 131: 4819-4829, 2004.

17. Jope RS, Yuskaitis CJ and Beurel E: Glycogen synthase kinase-3 (GSK3): inflammation, diseases, and therapeutics. Neurochem Res 32: 577-595, 2007.

18. Teller N, Thiele W, Marczylo TH, Gescher AJ, Boettler U, Sleeman J, et al: Suppression of the kinase activity of receptor tyrosine kinases by anthocyanin-rich mixtures extracted from bilberries and grapes. J Agric Food Chem 57: 3094-3101, 2009.

19. Huang HP, Shih YW, Chang YC, Hung CN and Wang CJ: Chemoinhibitory effect of mulberry anthocyanins on melanoma metastasis involved in the Ras/PI3K pathway. J Agric Food Chem 56: 9286-9293, 2008.

20. Nurwidya F, Takahashi F, Murakami A and Takahashi K: Epithelial mesenchymal transition in drug resistance and metastasis of lung cancer. Cancer Res Treat 44: 151-156, 2012.

21. Barrallo-Gimeno A and Nieto MA: The Snail genes as inducers of cell movement and survival: implications in development and cancer. Development 132: 3151-3161, 2005.

22. Kim D, Kim S, Koh H, Yoon SO, Chung AS, Cho KS, et al: $\mathrm{Akt} / \mathrm{PKB}$ promotes cancer cell invasion via increased motility and metalloproteinase production. FASEB J 15: 1953-1962, 2001. 
23. Peinado $\mathrm{H}$, Quintanilla $\mathrm{M}$ and Cano A: Transforming growth factor beta-1 induces snail transcription factor in epithelial cell lines: mechanisms for epithelial mesenchymal transitions. J Biol Chem 278: 21113-21123, 2003.

24. Lee J, Moon HJ, Lee JM and Joo CK: Smad3 regulates Rho signaling via NET1 in the transforming growth factor-betainduced epithelial-mesenchymal transition of human retinal pigment epithelial cells. J Biol Chem 285: 26618-26627, 2010.

25. Willis BC and Borok Z: TGF-beta-induced EMT: mechanisms and implications for fibrotic lung disease. Am J Physiol Lung Cell Mol Physiol 293: L525-L534, 2007.

26. Qiu Q, Yang M, Tsang BK and Gruslin A: EGF-induced trophoblast secretion of MMP-9 and TIMP-1 involves activation of both PI3K and MAPK signalling pathways. Reproduction 128: 355-363, 2004

27. Bouchard F, Belanger SD, Biron-Pain K and St-Pierre Y: EGR-1 activation by EGF inhibits MMP-9 expression and lymphoma growth. Blood 116: 759-766, 2010.

28. Stuelten CH, DaCosta Byfield S, Arany PR, Karpova TS, Stetler-Stevenson WG and Roberts AB: Breast cancer cells induce stromal fibroblasts to express MMP-9 via secretion of TNF-alpha and TGF-beta. J Cell Sci 118: 2143-2153, 2005.

29. Wang H, Wang HS, Zhou BH, Li CL, Zhang F, Wang XF, et al: Epithelial-mesenchymal transition (EMT) induced by TNF-alpha requires Akt/GSK-3beta-mediated stabilization of snail in colorectal cancer. PLoS One 8: e56664, 2013.
30. Yan D, Avtanski D, Saxena NK and Sharma D: Leptin-induced epithelial-mesenchymal transition in breast cancer cells requires beta-catenin activation via Akt/GSK3- and MTA1/Wnt1 protein-dependent pathways. J Biol Chem 287: 8598-8612, 2012.

31. Saito Y, Vandenheede JR and Cohen P: The mechanism by which epidermal growth factor inhibits glycogen synthase kinase 3 in A431 cells. Biochem J 303: 27-31, 1994.

32. Chen G, Bower KA, Xu M, Ding M, Shi X, Ke ZJ, et al: Cyanidin-3-glucoside reverses ethanol-induced inhibition of neurite outgrowth: role of glycogen synthase kinase 3 beta. Neurotox Res 15: 321-331, 2009.

33. Hudson TS, Hartle DK, Hursting SD, Nunez NP, Wang TT, Young HA, et al: Inhibition of prostate cancer growth by muscadine grape skin extract and resveratrol through distinct mechanisms. Cancer Res 67: 8396-8405, 2007.

34. Galbaugh T, Cerrito MG, Jose CC and Cutler ML: EGF-induced activation of Akt results in mTOR-dependent p70S6 kinase phosphorylation and inhibition of HC11 cell lactogenic differentiation. BMC Cell Biol 7: 34, 2006. 